Note

\title{
Bentonites modified with anionic and cationic surfactants for bleaching of crude palm oil
}

\author{
Nita Sofiani Gunawan ${ }^{\text {a }}$, Nani Indraswati a ${ }^{\text {a }}$ Yi-Hsu Ju ${ }^{\text {b }}$, Felycia Edi Soetaredjo ${ }^{\text {a }}$, \\ Aning Ayucitra ${ }^{\mathrm{a}, \mathrm{b}}$, Suryadi Ismadji ${ }^{\mathrm{a}, \mathrm{b}, *}$ \\ a Department of Chemical Engineering, Widya Mandala Surabaya Catholic University, Kalijudan 37, Surabaya 60114, Indonesia \\ ${ }^{\mathrm{b}}$ Department of Chemical Engineering, National Taiwan University of Science and Technology, 43, sec. 4 Keelung Rd., Taipei, 106 Taiwan
}

\section{A R T I C L E I N F O}

Article history:

Received 10 October 2009

Received in revised form 9 November 2009

Accepted 16 November 2009

Available online 26 November 2009

Keywords:

Organo-bentonite

Bleaching

Palm oil

\section{A B S T R A C T}

Bentonite Pacitan was modified with cetyl trimethylammonium bromide (CTAB) and LAS for bleaching crude palm oil. The organo-bentonites were prepared by normal heating and microwave irradiation. The advantage of using microwave irradiation is time efficiency. The bentonites were characterized by FTIR and XRD analysis. LAS modified bentonite was more effective as bleaching agent than CTA-bentonite.

(c) 2009 Elsevier B.V. All rights reserved.

\section{Introduction}

The chemical nature and pore structure of bentonites generally determine their adsorption ability (Juang et al., 2002; Koyuncu, 2008). Because of hydrophilicity bentonites are usually not effective in adsorbing organic compounds. The adsorption capacity can be improved by surface-modification (Bergaya et al., 2006; Komadel and Madejova, 2006; Lagaly et al., 2006; Churchman et al., 2006; Khenifi et al., 2007; Ma and Zhu, 2007; Akimbaeva and Ergozhin, 2007; Koyuncu, 2008; Zhu et al., 2008). Bentonites are usually modified by alkaline, acid, and organic activation.

Bentonite is found in various regions in Indonesia in huge and abundant quantity, from the west to the east part of Indonesia. Currently, the major use of this material is for purification of crude palm oil and as drilling mud. The bentonite (then known as bleaching agent) used for discolouring crude palm oil usually is obtained by reacting bentonite with hot inorganic acids. The available acid-activated bentonite in Indonesian local market usually has very low pH value (due to excess use of acid) and is unstable in terms of quality. The use of these kinds of acid-activated bentonite for the purification of palm oil often creates many problems to oil companies such as corrosion of the process vessels, increasing of FFA (free fatty acid) and PV (peroxide

\footnotetext{
* Corresponding author. Department of Chemical Engineering, Widya Mandala Surabaya Catholic University, Kalijudan 37, Surabaya 60114, Indonesia. Tel.: +62 313891264; fax: + 623891267.

E-mail address: suryadiismadji@yahoo.com (S. Ismadji).
}

value) in oil products, etc. Furthermore, the excessive use of acid during activation can cause environmental problems.

In our study bentonite was modified with cationic and anionic surfactants and used for colour removal of low quality crude palm oil.

\section{Materials and methods}

The bentonite was obtained from a bentonite mining site located in Pacitan, East Java, Indonesia. The raw material was dried at $105{ }^{\circ} \mathrm{C}$ for $24 \mathrm{~h}$ and ground to obtain the particles $<60 / 80$ mesh. The cation exchange capacity of bentonite was determined to be $0.47 \mathrm{meq} / \mathrm{g}$ on the basis of the ASTM C837-99 procedure. Brief descriptions of the procedure are as follows: $300 \mathrm{~mL}$ of distilled water was added to $2 \mathrm{~g}$ of dried bentonite, the mixture stirred until the bentonites were uniformly dispersed. The $\mathrm{pH}$ of the slurry was measured; then sufficient amount of sulfuric acid was added to the slurry to bring the $\mathrm{pH}$ within the range from 2.5 to 3.8. The stirring was continued while the $\mathrm{pH}$ was being adjusted. With the slurry still under the mixer, the buret was filled with methylene blue solution, and $5 \mathrm{~mL}$ of methylene blue was added to the slurry, and stirred for $2 \mathrm{~min}$. One drop of the slurry was placed on the edge of the filter paper. The end point was indicated by the formation of a light blue halo around the drop. Surfactants used in this experiment were cetyl trimethylammonium bromide (CTAB) and linear alkylbenzene sulfonate (LAS), purchased from Sigma Aldrich in analytical grade and used without any further treatment.

The organo-bentonite was prepared by normal heating and microwave irradiation. The amount of the surfactants added was 1.5 times of cation exchange capacity (CEC). In the conventional method, $25 \mathrm{~g}$ bentonite was mixed with $250 \mathrm{~mL}$ surfactant solutions and shaken for 
$24 \mathrm{~h}$ using a thermostatic shaker bath at $30^{\circ} \mathrm{C}$. The bentonite was separated by centrifugation at $5000 \mathrm{rpm}$ for $15 \mathrm{~min}$, washed several times with $500 \mathrm{~mL}$ deionised water, dried at $105^{\circ} \mathrm{C}$ for $2 \mathrm{~h}$ and ground to pass 200 mesh. Microwave irradiation was conducted using $700 \mathrm{~W}$ microwaves power for $2 \mathrm{~min}$.
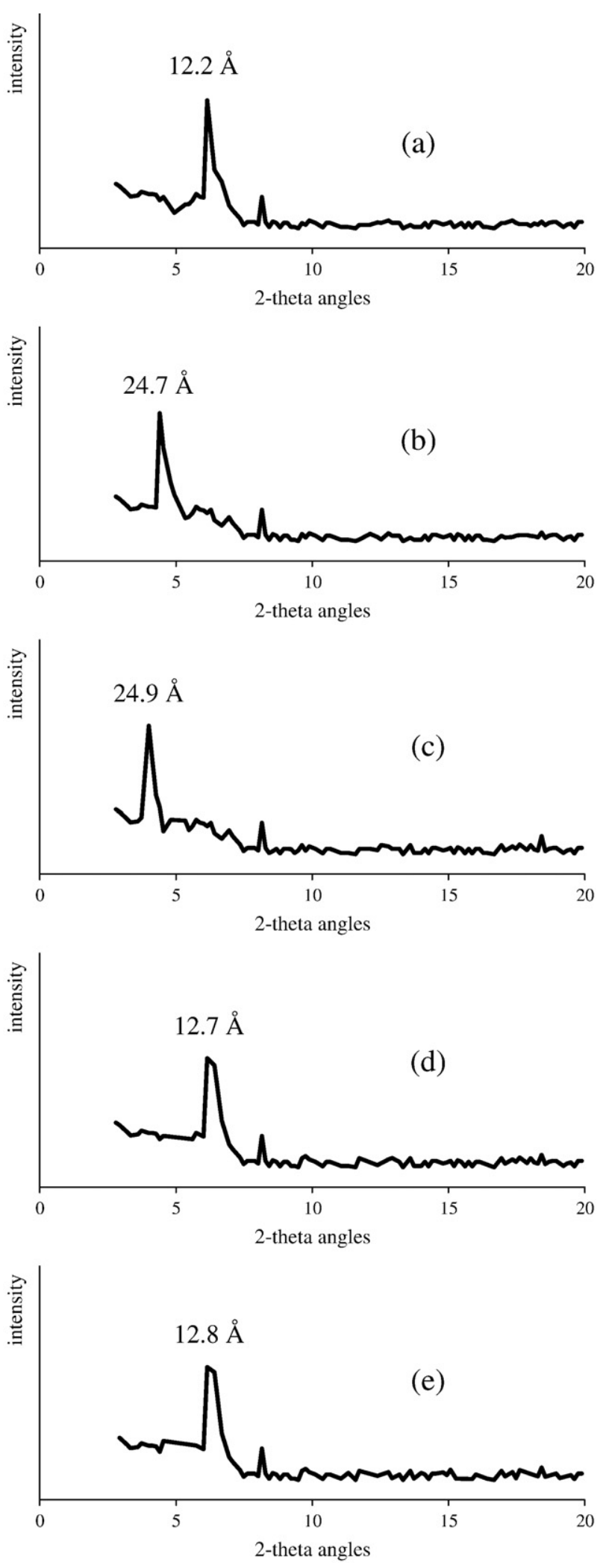

Fig. 1. XRD patterns of (a) B, (b) COC, (c) COM, (d) LOC, and (e) LOM.
Table 1

$R$ (colour removal), FFA (decrease of free fatty acid content), PV (peroxide value) on degummed and bleached palm oil.

\begin{tabular}{llll}
\hline Oil & R (\%) & FFA (\%) & PV \\
\hline Degummed & - & 6.7813 & 1.4 \\
Bleached B & $49.35 \%$ & 6.7457 & 0.4 \\
Bleached COC & $30.00 \%$ & 6.4661 & 0.3 \\
Bleached COM & $31.05 \%$ & 6.0600 & 0.3 \\
Bleached LOC & $65.26 \%$ & 6.4279 & 0.3 \\
Bleached LOM & $65.44 \%$ & 6.0622 & 0.3 \\
\hline
\end{tabular}

Bleaching of crude palm oil process was performed using five different adsorbents: bentonite (B), CTA-bentonite prepared by conventional heating (COC) and microwave irradiation (COM), and LAbentonites LOC and LOM. The amount of adsorbent used in the bleaching process was $3 \%(\mathrm{~m} / \mathrm{v})$ of degummed palm oil.

Total colour, free fatty acid content (FFA) and peroxide value (PV) of degummed palm oil and bleached palm oil were analyzed by several methods. The colour of palm oil was determined in a lovibond tintometer and the colour removal was calculated using Khrisnan equation (Srasra et al., 1989) as follows:

$R=\frac{\text { total colour of }(\text { degummed palm oil }- \text { bleached palm oil })}{\text { total colour of degummed palm oil }} \times 100 \%$.

FFA and PV analyses were conducted according to the AOAC Official Method 940.28 and 965.33.

\section{Results and discussions}

The XRD patterns are shown in Fig. 1 together with the $\mathrm{d}_{001}$-value (basal spacing). The basal spacing of $\mathrm{COC}$ and $\mathrm{COM}$ was increased to $24.7 \AA$ and $24.9 \AA$, due to the intercalation of CTAB present in the bentonite ( $\mathrm{Li}$ et al., 2006). As expected, LAS was not intercalated and the basal spacing of LOC and LOM remained at $12.7 \AA$ and $12.8 \AA$.

All adsorbents (Table 1 ) reduced the colour of degummed crude palm oil. The highest colour removal was observed with LOM. The reason of the enhanced carotene adsorption is probably the interaction between the nuclei of LAS and carotene as shown in Fig. 2b, bentonite with its hydrophilic surface was not very effective in bleaching of palm oil. Molecular simulation using MM2 in Chem3D (Cambridge Soft) shows that steric hindrance of adsorption of $\beta$-carotene on CTA-bentonite was higher than on LA-bentonite. Thus, adsorption of $\beta$-carotene onto LA-bentonite is more favored than on CTA-bentonite, improving colour removal.

In general, the modification of Pacitan bentonite gave no significant effect on FFA removal during the bleaching process (Table 1). However, a significant decreased in PV value was observed. The decrease of the PV value during the bleaching process was due to the adsorption of peroxide compounds and transformation of peroxide into secondary oxidation products and followed by the adsorption of secondary oxidation products on the organo-bentonite particles (Rossi et al., 2003).

\section{Conclusion}

All bentonites used in this study reduced the colour of degummed crude palm oil. The highest effect was reached by bentonite modified with LAS during microwave heating.

\section{Acknowledgements}

The authors acknowledge the funding of this work through the National Taiwan University of Science and Technology-Widya Mandala Surabaya Catholic University joint research project with contract no RP09-01 and the Directorate General of Higher Education Republic of Indonesia through a competitive grant for international publication with contract number 676/SP2H/PP/DP2M/VII/2009. 


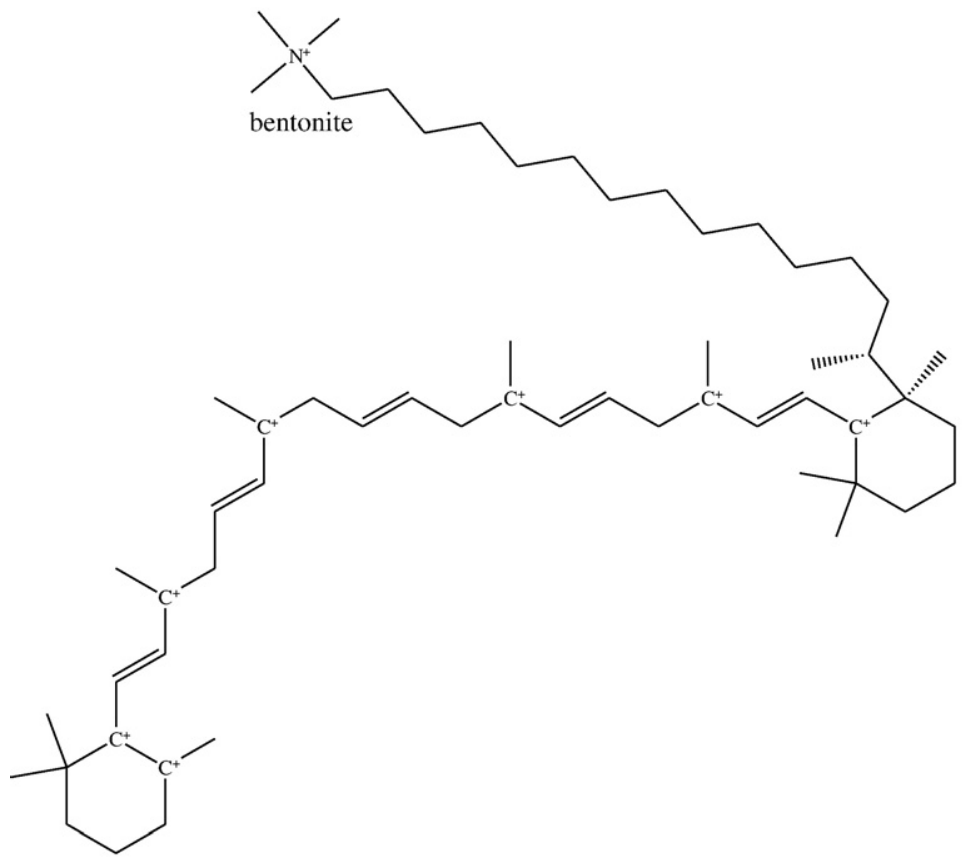

(a)

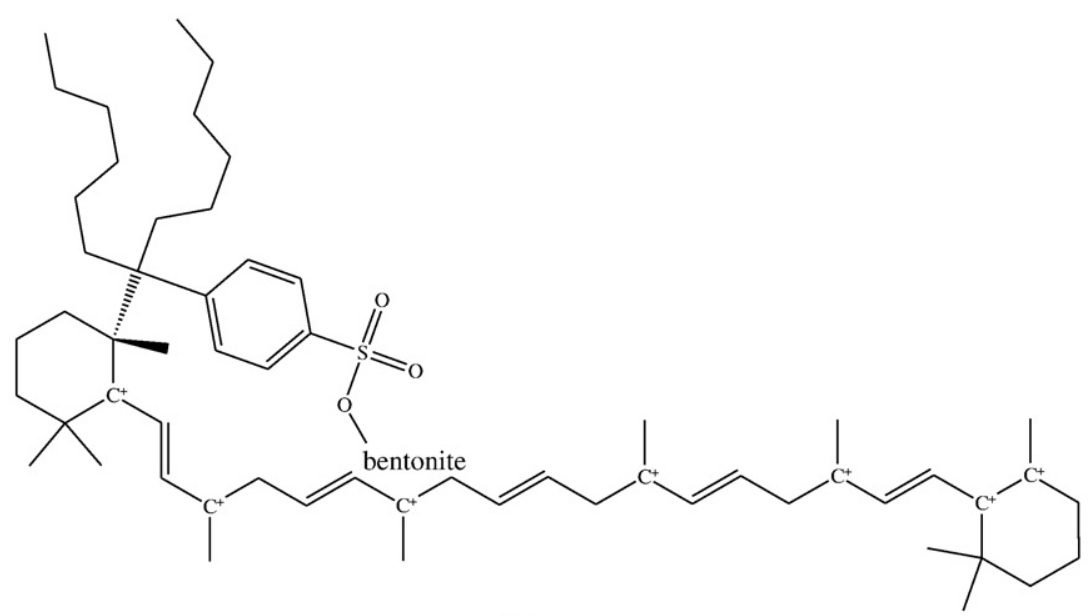

(b)

Fig. 2. Adsorption $\beta$-carotene on (a) CTA-bentonite and (b) LA-bentonite.

\section{References}

Akimbaeva, A.M., Ergozhin, E.E., 2007. Estimation of structural and sorption characteristics of activated bentonite. Colloid Journal 69, 401-406.

Bergaya, F., Theng, B.K.G., Lagaly, G., 2006. Modified clays and clay minerals. In: Bergaya, F., Theng, B.K.G., Lagaly, G. (Eds.), Handbook of Clay Sciences, vol. 1. Elsevier, p. 261. Churchman, G.J., Gates, W.P., Theng, B.K.G., Yuan, G., 2006. Clays and clay minerals for pollution control. In: Bergaya, F., Theng, B.K.G., Lagaly, G. (Eds.), Handbook of Clay Sciences, vol. 1. Elsevier, pp. 625-675.

Juang, R.S., Lin, S.H., Tsao, K.H., 2002. Mechanism of sorption of phenols from aqueous solutions onto surfactant-modified montmorillonite. Journal of Colloid and Interface Science 254 (2), 234-241.

Khenifi, A., Bouberka, Z., Sekrane, F., Kameche, M., Derriche, Z., 2007. Adsorption study of an industrial dye by an organic clay. Adsorption 13 (2), 149-158.

Komadel, P., Madejova, J., 2006. Acid activation of clay minerals. In: Bergaya, F., Theng, B.K.G., Lagaly, G. (Eds.), Handbook of Clay Sciences, vol. 1. Elsevier, pp. 263-287.
Koyuncu, H., 2008. Adsorption kinetics of 3-hydroxybenzaldehyde on native and activated bentonite. Applied Clay Science 38, 279-287.

Lagaly, G., Ogawa, M., Dekany, I., 2006. Clay mineral organic interactions. In: Bergaya, F., Theng, B.K.G., Lagaly, G. (Eds.), Handbook of Clay Sciences, vol. 1. Elsevier, pp. 309-377.

Li, J., Zhu, L., Cai, W., 2006. Characteristics of organobentonite prepared by microwave as a sorbent to organic contaminants in water. Colloids and Surfaces A: Physicochem. Eng. Aspects 281, 177-183.

Ma, J., Zhu, L., 2007. Removal of phenols from water accompanied with synthesis of organobentonite in one-step process. Chemosphere 68, 1883-1888.

Rossi, M., Gianazza, M., Alamprese, C., Stanga, F., 2003. The role of bleaching clays and synthetic silica in palm oil physical refining. Food Chemistry 82, 291-296.

Srasra, E., Bergaya, F., Damme, H.V., Ariguib, N.K., 1989. Surface properties of an activated bentonite decolorization of rape seed Oil. Applied Clay Science 4, 411-421.

Zhu, L., Ruan, X., Chen, B., Zhu, R., 2008. Efficient removal and mechanisms of watersoluble aromatic contaminants by a reduced-charge bentonite modified with benzyltrimethylammonium cation. Chemosphere 70, 1987-1994. 